\title{
IMPLEMENTASI KEBIJAKAN PENCEGAHAN DAN PENANGGULANGAN HIVIAIDS DI KOTA PALANGKA RAYA PROVINSI KALIMANTAN TENGAH
}

\section{Implementation of the HIVIAIDS Prevention and Control Policy in the City of Palangka Raya, Central Kalimantan Province}

\section{Nurhasanah* \\ Yuliana}

\begin{abstract}
Universitas Muhammadiyah Palangkaraya, Palangka Raya, Central Kalimantan, Indonesia
\end{abstract}

email: nurhasanah@umpalangkaraya.ac.id

\section{Kata Kunci:}

Implementasi Kebijakan

Penanggulangan

HIVIAIDS

\section{Keywords:}

Policy Implementation

Prevention

HIVIAIDS

Accepted

June 2016

Published

October 2016

\begin{abstract}
Abstrak
Tujuan dari penelitian ini yaitu untuk mengetahui implementasi Kebijakan Pencegahan dan Penaggulangan HIVIAIDS di Kota Palangka raya Provinsi Kalimantan Tengah. Metode yang digunakan dalam penelitian ini adalah metode kualitatif dengan Teknik observasi, wawancara, dan dokumentasi. Sumber data dalam penelitian ini adalah pegawai Dinas Kesehatan dan Masyarakat Kota Palangka Raya. Hasil penelitian menunjukan bahwa implementasi Kebiajakan Pencegahan dan Penanggulangan HIVIAIDS diKota Palangka Raya belum sesuai dengan yang tertuang di Peraturan Daerah Nomor 8 Tahun 20II. Dinas Kesehatan sudah menangani orang-orang yang terinfeksi belum terlaksana dengan maksimal. Penanganan yang dilakukan yaitu mulai dari sosialisasi, Penertiban dan usaha rehabilitasi. Dinas Kesehatan belum melakukan sosialisasi sepenuhnya dikalangan masyarakat Kota Palangka Raya, masih belum adanya kerja sama yang memuaskan antara lembaga maupun organisasi yang dibentuk untuk masalah pencegahan dan penanggulangan penyakit HIVIAIDS. Kendala-kendala yang mengahambat Dinas Kesehatan dalam mengimplementasi adalah kurangnya sarana dan prasarana seperti tempat penaggulangan khusus, masalah pendanaan serta tenaga kerja yang siap dalam melaksanakan Program pencegahan dan penanggulangan HIVIAIDS.
\end{abstract}

\begin{abstract}
The purpose of this study is to determine the implementation of the HIVIAIDS Prevention and Prevention Policy in Palangka Raya City, Central Kalimantan Province. The method used in this study is a qualitative method with observation, interview, and documentation techniques. The data sources in this study were employees of the Health Office and Community of the City of Palangka Raya. The results showed that the implementation of the HIVIAIDS Prevention and Control Policy in Palangka Raya City was not in accordance with what was stated in Regional Regulation Number 8 of 2011 . The Health Office had handled the infected people to the maximum. Handling is carried out, namely starting from socialization, control and rehabilitation efforts. The Health Office has not fully carried out socialization among the people of the City of Palangka Raya, there is still no satisfactory cooperation between institutions and organizations formed for the problem of prevention and control of HIVIAIDS. The obstacles that hamper the Office of Health in implementing are the lack of facilities and infrastructure such as special remedies, funding issues, and workers who are ready to implement the HIVIAIDS prevention and prevention program.
\end{abstract}

\section{PENDAHULUAN}

Di Indonesia khususnya dikota palangka raya masalah penyakit HIV ini Masih belum jelas penanganannya dan penanggulangannya secara serius terlihat dari kebebasan masyarakat baik dari kalangan anak-anak, remaja bahkan sampai orang dewasa sekalipun dalam melakukan tindakan yang bisa menimbulkan dan menularkan penyakir HIV. Misalnya seperti anak-anak yang masih kecil saja sudah mengenal dunia bebas dengan menggunakan obat-obatan terlarang bahkan lebih parah lagi bisa sampai menggunakan narkoba suntik dengan bergantian. Mereka tidak sadar apa yang dilakukan itu menimbulan penyakit dan sekaligus menularkan bakteri HIV karenaa penyakit ini walaupun tidak menggunakan jarum suntik melalu makanan yang dimakan oleh satu orang yang menderita penyakit HIV kemudian dimakan oleh temannya yang sehat maka otomatis bisa tertular. 
Hal semacam itu saja dapat menimbulkan penyakit HIV bagaimana dengan orang dewasa yang melakukan hubungan seksual secara bebas. Karena bisa kita ketahui diderah palangka raya ini Lokasi prostitusi banyak menyebar dimana-mana, baik didaerah Cilik Riwut kilometer 12, jalan Lintas Mahir Mahar, bahkan didaerah kalampangan sekalipun, dimana banyak pekerja seks komersial (PSK) yang jumlahnya setiap tahun terus meningkat tanpa adanya izin dari pemerintah kota palangkaraya. PSK yang bekerja di lokasi prostitusi di tersebut besar kemungkinan berpotensi terkena penyakit AIDS. Di samping tingkat pendidikan mereka rata-rata rendah, pengetahuan mereka tentang penyakit HIVIAIDS juga masih rendah. $\mathrm{Hal}$ ini terbukti dengan adanya anggapan bahwa penyakit HIVIAIDS hanya menular pada kaum homoseksual saja.

Menurut Van Meter dan Van Horn (2006:65) bahwa Implementasi adalah "tindakan-tindakan yang dilakukan baik oleh individu- individu/pejabat-pejabat atau kelompok-kelompok pemerintah atau swasta yang diarahkan pada tercapainya tujuan-tujuan yang telah digariskan dalam keputusan kebijakan. Menurut Mazmanian dan Sabatier (Widodo,2010:87) pada hakikatnya yang utama implementasi kebijakan adalah memahami apa yang seharusnya terjadi sesudah suatu program dinyatakan berlaku atau dirumuskan. Pemahaman tersebut mencakup usaha-usaha untuk mengadministrasikannya dan menimbulkan dampak nyata pada masyarakat atau kejadian-kejadian.

Menurut Ripplay da Franklin (Tangkilisan, 2003 :14) menyatakan bahwa keberhasilan implementai kebijakan program dapat dipengaruhi oleh tiga faktor, yaitu :

I. Persfektif kepatuhan (compliance) yang mengukur implementasi dari kepatuhan strate level bureaucracy terhadap atas mereka.

2. Kelancaran rutinitas dan ketiadaan persoalan.

3. Kinerja yang memuaskan semua pihak terutama kelompok penerima manfaat yang diharapkan
Acquired Immune Deficiency Syndrome (AIDS) merupakan kumpulan gejala penyakit yang disebabkan oleh virus HIV ( Human Immuno Deficiency Virus ) yang akan mudah menular dan mematikan. Virus tersebut merusak sistem kekebalan tubuh manusia, dengan berakibat yang bersangkutan kehilangan daya tahan tubuhnya, sehingga mudah terinfeksi dan meninggal karena berbagai penyakit infeksi kanker dan lain-lain. Sampai saat ini belum ditemukan vaksin pencegahan atau obat untuk penyembuhannya

Ada empat cara penularan HIV. Pertama, melalui hubungan seksual dengan seorang pengidap HIV tanpa perlindungan atau menggunakan kontrasepsi (kondom). Cara kedua, HIV dapat menular melalui transfusi dengan darah yang sudah tercemar HIV. Cara ketiga, seorang ibu yang mengidap HIV bisa pula menularkannya kepada bayi yang dikandung, itu tidak berarti HIV IAIDS merupakan penyakit turunan, karena penyakit turunan berada di gen-gen manusia sedangkan HIV menular saat darah atau cairan vagina ibu membuat kontak dengan cairan atau darah anaknya. Dan cara keempat adalah melalui pemakaian jarum suntik akufuntur, jarum tindik dan peralatan lainnya yang sudah dipakai oleh pengidap HIV. Berikut ini beberapa cara pencegahan penyakit HIVIAIDS :

I. Setialah dengan suami atau istri anda. Lakukan hubungan seksual hanya dengan pasangan hidup anda (safe sex).

2. Menghindari seks bebas (free sex). Jangan melakukan hubungan badan dengan pekerja seksual (PSK) atau berganti-ganti pasangan.

3. Gunakan kondom secara benar dalam berhubungan seksual, kecuali untuk pasangan-pasangan yang menginginkan bayi. Kondom bisa menurunkan resiko infeksi tetapi tidak dapat mencegahnya secara total. Kondom yang terbuat dari selaput (membrane) binatang terlalu tipis untuk dapat melindungi. 
4. Hindari penyalah-gunaan obat terlarang, narkoba dan penggunaan jarum suntik bersama-sama.

5. Bila ingin akupunctur, tattoo, atau tindik telinga pastikan bahwa alat-alat yang dipakai telah disterilkan.

6. Bila perlu operasi, sebaiknya minta transfuse darah autologous, yaitu donor darah untuk nantinya dipakai sendiri

\section{METODOLOGI}

Penelitian ini penulis menggunakan metode penelitian deskriptif kualitatif. Penelitian kualitatif adalah penelitian tentang riset yang bersifat deskriptif dan cenderung menggunakan analisis. Karena penelitian ini ingin mengetahui keseluruhn tentang Implementasi Kebijakan Pencegahan dan Penanggulangan HIVIAIDS maka dalam penelitian ini pendekatan yang dilakukan adalah melalui pendekatan kualitatif. Artinya data yang dikumpulkan bukan berupa angka-angka meliankan data tersebut berasal dari naskah wawancara,catatan lapangan, dokumen pribadi, catatan nemo, dan dokumen resmi lainnya.

\section{HASIL DAN PEMBAHASAN}

Berdasarkan Hasil penelitian dengan menggunakan teori Ripplay dan Franklin (Tangkilisan, 2003:14) dilakukan Analisa melalui berbagai perspektif sebagai berikut:

\section{Berdasarkan Perspektif Kepatuhan}

Dalam melaksanakan tugasnya Dinas Kesehatan Palangka Raya sudah menangani orang-orang yang terinfeksi virus HIVIAIDS tetapi belum terealisasi semaksimal mungkin dikarenakan adanya kendala dan sebab yaitu dalam hal pendanaan yang dalam melaksanakan kegiatannya tidak dapat maksimal, pelaksanaan sosialisasi yang belum merata dan pengawasan yang tidak menyeluruh walaupun sudah bekerja sama dengan pihak dari Komisi Penanggulangan
AIDS, Lembaga Swadaya Masyarakat dan organisasi yang dibentuk sendiri oleh mereka yang terinfeksi tetapi hal ini masih belum memaksimalkan efektifnya kebijakan ini.

Kelancaran Rutinitas dan Tiadanya Persoalan

Kendala-kendala yang dihadapi Pemerintah Kota Palangka Raya yaitu Dinas Kesehatan Kota Palangka Raya ini yang menghambat kinerja dalam menjalankan tugasnya untuk mengurangi dan memberantas penyakit menular yang menyebar saat ini antaralain kurangnya pendanaan, sarana dan prasarana yang merupakan syarat untuk dapat sosialisasi, merehabilirasi dan pengobatan serta pengawasan, dan sementara yang dilakukan pada saat sekarang berupa bimbingan mental, bimbingan sosial dan pengawasan.

Kinerja yang Memuaskan Semua Pihak

Upaya yang dilakukan untuk Implementai Kebijakan Pencegahan dan Penanggulangan HIVIAIDS di Kota Palangka Raya ditetapkan pemerintah dalam hal ini tugas dan fungsi yang menerapkan adalah Dinas Kesehatan Kota Palangka Raya, peneliti dapat menyimpulkan bahwa dalam menjalankan tugas dan memuaskan semua pihak belum teroganisir dengan baik karena dalam program bimbingan mental dan bimbingan sosial tidak berjalan secara keseluruhan terkendala daru tenaga bantu, dan pelaksanaan yang tersendat-sendat hal ini dikarenakan pihak dari rumah sakit terdekat yang sudah bekerjasama dengan dinas Kesehatan tidak sepenuhnya mampu melayani dan memberikan fasilitas sesuai ketentuan. Tempat program yang dilaksanakan Dinas Kesehatan Kota Palangka Raya yaitu rehabilitasi dan pengobatan yang beserta bimbingan mental dan bimbingan social untuk saat ini belum ada. 


\section{KESIMPULAN}

Dalam implementasi Dinas Kesehatan Kota Palangka Raya sudah menjalankan tugasnya tetapi belum maksimal karena banyaknya kendala yang dialami walaupun sudah bekerja sama dengan beberapa pihak organisasi dan lain sebagainya tapi itu belum memberikan dampak yang sangat maksimal untuk kesejahteraan masyarakat. Adapun kendala-kendala dan masalah yang menjadi menghambat kelancarannya rutinitas yang dialami oleh Dinas Kesehatan kota Palangka Raya dalam melaksanakan implementasi Kebijakan pencegahan dan penanggulangan HIVIAIDS yaitu kurangnya sarana dan prasarana seperti fasilitas pengobatan dan terbatasnya biaya untuk menangani masyarakat yang positif terinfeksi terkena penyakit menular HIVIAIDS yang dapat mematikan serta kurangnya kegiatan secara langung yang merata dikalangan masyarakat yang sifatnya membangun dan membimbing masyarakat. Meskipun sudah bekerjasama dengan Lintas Sektor dan Komisi Penanggulangan AIDS serta organisasi yang dibentuk didalam masyarakat itu sendiri tetapi masih belum bisa memberikan sosialisasi dan pemberitahuan secara umum kepada masyarakat luas dengan maksimal selain itu tenaga khusus yang disiapkan untuk pengobatan itu belum ada masih bergantung kepada tenaga kerja yang memiliki tugas lain sehingga banyak dari masyarakat juga memberikan keluhan tentang kurang siapnya kinerja yang menjalankan tugas selain itu juga terbatasnya fasilitas yang ada.

\section{REFERENSI}

Agustino, Leo. 2014. Dasar-dasar Kebijakan Publik. Bandung: Alfabeta.

Anggara, Sahya.2012,Ilmu Administrasi Negara, Bandung:CV Pustaka Setia.

Bodgan,Robert. Participant Observation in Organizational settings, syracuse, N.Y,Syracuse University press

Karunianto, M.O. 2016. Kinerja Bidang Rekam Medik Di Lingkungan Rumah Sakit Umum Daerah Kasongan Kabupaten Katingan Provinsi Kalimantan Tengah. Pencerah Publik. 3(2):4859.

Mambang, M., Harry, W.F. 2016. Implementasi Kebijakan Gelandangan, Pengemis, Tuna Susila Dan Anak Jalanan Di Kota Palangka Raya Provinsi Kalimantan Tengah. Pencerah Publik. 3(2): I-8.

Peraturan Daerah Kota Palangka Raya Nomor 8 tahun 20II Tentang Pencegahan dan Penanggulangan HIVIAIDS.

Sugiyono AG. 2015. Analisis Kebijakan Publik Konsep Teori dan Aplikasi. Yogyakarta : Pustaka Pelajar.

Tangkilisan, Hessel Nogi S. 2002. Kebijakan dan Manajemen Otonomi Daerah.Yogyakarta: Lukman Offset

Wahab,Abdul Solichin. 20I5. Analisis Kebijakan dari Formulasi kepenyusunan model-model Implementasi kebijakan Publik. Jakarta :PT Bumi Aksara

Widodo, Joko. 2016. Analisis Kebijakan Publik Konsep dan Aplikasi Analisis Proses Kebijakan Publik, Malang : Media Nusa Kreative. 